\title{
Editorial
}

\section{Fisioterapia: uma ciência baseada em evidências}

O surgimento da Fisioterapia no Brasil foi influenciado pela vinda da Família Real ao país e ao uso das chamadas "Casas de Duchas". Durante muitos anos, os recursos fisioterápicos faziam parte da terapêutica médica e a forma de atuação nesse período (século XIX) parecia restringir a Fisioterapia como apenas "reabilitadora" e não como ramo da ciência ${ }^{1}$.

Os fisioterapeutas baseavam-se em livros de reabilitação os quais, em sua maioria, eram importados e que descreviam "receitas prontas", o que restringia o discernimento crítico diante do grande arsenal de recursos terapêuticos disponíveis e tornava a tomada de decisão clínica um ato complexo.

Hoje, devidamente regulamentada, a Fisioterapia é uma Ciência da Saúde que estuda, previne e trata os distúrbios cinéticos funcionais intercorrentes em órgãos e sistemas do corpo humano, gerados por alterações genéticas, por traumas e por doenças adquiridas² ${ }^{2}$ além de ser uma prática clínica totalmente alicerçada em evidências e pesquisas.

O profissional é dotado de habilidades que o possibilita atuar em todos os níveis de atenção à saúde e em equipes multidisciplinares, contribuindo para a manutenção da saúde, bem estar e qualidade de vida.

Cabe ao fisioterapeuta avaliar, estabelecer o diagnóstico fisioterapêutico, definir as intervenções e realizar as reavaliações necessárias. A pró-atividade é o princípio da pesquisa e certamente contribui e continuará sendo a base para os avanços no setor.

Nesta edição, a Revista Fisioterapia em Movimento contempla o leitor com artigos originais que evidenciam a atuação fisioterápica nas áreas de Ortopedia, Dermatofuncional, Cardiorrespiratória, Saúde Coletiva e Neurofuncional. Ainda, conta com revisões no âmbito da Fisioterapia Pediátrica Neonatal e Terapia Intensiva. Estas publicações são um retrato da pesquisa na área e objetos motivacionais para a busca contínua por aprimoramento e a produção de novos conhecimentos.

Boa leitura!

Dra. Drielen de Oliveira Moreira

1 BOTOMÉ, S. P.; REBELATTO, J. R. Fisioterapia no Brasil: fundamentos para uma ação preventiva e perspectivas profissionais. 2. ed. São Paulo: Manole,1999.

2 Conselho Federal de Fisioterapia e Terapia Ocupacional: RESOLUÇÃO №. 80, DE 9 DE MAIO DE 1987. (Diário Oficial da União no 093 - de 21/05/87, Seção I, Págs. 7609), acessado em 24 de abril de 2008. 